\title{
Sustainable Change
}

\section{Education for Sustainable Development in the Business School}

\author{
Kyoko Fukukawa, David Spicer and Sally Ann Burrows \\ Bradford University School of Management, UK \\ Jenny Fairbrass \\ Norwich Business School; University of East Anglia, UK
}

This paper examines the implementation of education for sustainable development (ESD) within a business school. ESD is of growing importance for business schools, yet its implementation remains a challenge. The paper examines how barriers to ESD's implementation are met through organisational change as a 'sustainable' process. It evaluates change brought about through ESD in a UK-based business school, through the lens of Beer and Eisenstat's three principles of effective strategy implementation and organisational adaptation, which state: 1) the change process should be systemic; 2) the change process should encourage open discussion of barriers to effective strategy implementation and adaptation; and 3) the change process should develop a partnership among all relevant stakeholders. The case incorporates, paradoxically, both elements of a top-down and an emergent strategy that resonates with elements of life-cycle, teleological and dialectic frames for process change. Insights are offered into the role of individuals as agents and actors of institutional change in business schools. In particular, the importance of 'academic integrity' is highlighted for enabling and sustaining integration. Findings also suggest a number of implications for policy-makers who promote ESD, and for faculty and business school managers implementing, adopting and delivering ESD programmes.

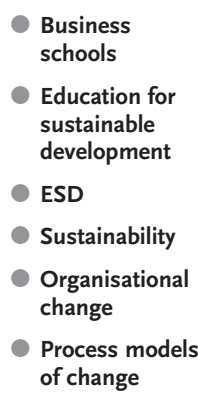

Dr Kyoko Fukukawa is a Senior Lecturer in Marketing at Bradford University School of Management and specialises in research on CSR and ethical decision-making in consumption and business practices. She edited a book titled Corporate Social Responsibility in Asia (2010, Routledge). She was a Japanese Studies Fellow of the Japan Foundation in 2006, when she conducted research in multinational companies on the communication and practice of CSR in Japan. She is an editorial board member of Asian Journal of Business Ethics. She also co-edited a special issue of the Journal of Business Ethics on Corporate Identity, Ethics and CSR (2007).

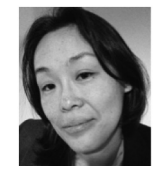

$\triangle$ Bradford University School of Management, Emm Lane, Bradford BD9 4JL, UK

k.fukukawa@bradford.ac.uk
Dr David Spicer is a Senior Lecturer in Organisational Change and Head of the Human Resource Management Group at Bradford University School of Management. His research is concerned with organisational learning and change. His current work is concerned with strategic adaptation, and sustainable organisational learning and change. He has undertaken research and consulted on change in both public and private sectors and is currently studying strategic adaptation and dynamic capabilities in high-tech multinationals facing radical change.

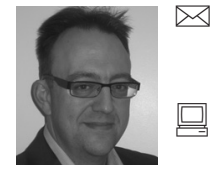

Bradford University School of Management, Emm Lane, Bradford BD9 4JL, UK

D.P.Spicer@bradford.ac.uk 
Dr Jenny Fairbrass was a Senior Lecturer in Corporate Social Responsibility at the University of Bradford's School of Management and is now employed at the Norwich Business School as a Senior Lecturer in Business and Management. Her research is multi- and trans-disciplinary, encompassing political science, environmental studies and management studies. Jenny's research focuses on sustainability, corporate social responsibility (CSR) and the environment with a particular focus on energy and climate change issues. She primarily investigates public policy, governance and business lobbying/interest representation. The geographical scope of her work covers primarily EU countries and Asia.

Sally Ann Burrows is a Senior Lecturer in Marketing, and has had extensive business experience before her career in academia. She was the Associate Dean at Bradford University School of Management for a number of years, and chaired the task force committee set up to engage students and staff in sustainability in the school. Her research interests are in creativity and sensory marketing, particularly those areas where sensory triggers are used in marketing and brand management.

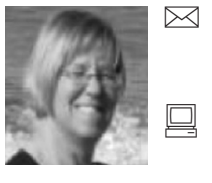

Norwich Business School, University of East Anglia, Norwich, Norfolk NR4 7TJ, UK

j.fairbrass@uea.ac.uk

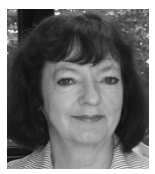

Bradford University School of Management, Emm Lane, Bradford BD9 4JL, UK 
HIS PAPER EXAMINES THE PROCESS of implementing education for sustainable development (ESD) within the context of the business school. In particular, it examines how barriers to the implementation of ESD are met through organisational change as a 'sustainable' process. There is no agreed definition of ESD; however $\mathrm{UNESCO}^{1}$ defines ESD thus:

\begin{abstract}
Education for Sustainable Development means including key sustainable development issues into teaching and learning; for example, climate change, disaster risk reduction, biodiversity, poverty reduction, and sustainable consumption. It also requires participatory teaching and learning methods that motivate and empower learners to change their behaviour and take action for sustainable development. Education for Sustainable Development consequently promotes competencies like critical thinking, imagining future scenarios and making decisions in a collaborative way.
\end{abstract}

This definition suggests that ESD affects not just the content of education but also its process and outcomes. It presents a perspective on ESD suggesting that it offers an agenda for educators and students to look at how they can make positive changes to support sustainability through their own actions and behaviour. This, in part, suggests why ESD is of growing importance to business schools (Ghoshal 2005; Rands and Starik 2009; Starik et al. 2010). Criticisms of business schools in the wake of the financial crisis linked the limitations of business school-educated executives to curricula focused on process efficiency and profit maximisation and have suggested that those curricula needed to consider more ethical approaches to business; a focus on sustainability is argued as inextricably linked to this (Cornelius et al. 2007).

While the focus of this paper is on the business school, the changes described here formed part of wider moves at the University of Bradford (UK) to position the university as a centre of excellence for sustainability education and research. The example of ESD implementation considered was therefore part of the university's wider sustainability initiative and a university-wide policy requirement for schools to include ESD in formal curricula. As these changes were set only in policy terms by the university and the detailed action for implementation of this policy was decided at school level, we have focused on the university's business school where this programme was pursued purposefully, and all the authors were involved in the implementation. This is within the context of the wider university sustainability agenda and the findings and discussion nonetheless address implications of this change at both school and university levels.

The business school considered is a full-service business school with undergraduate, postgraduate (taught, including an MBA and research, both DBA and $\mathrm{PhD}$ ) and executive education programmes. While some studies do offer an account of changes implemented at programme or module level (see Pesonen 2003 and Kurland et al. 2010 for examples), this study provides an example of

1 www.unesco.org/new/en/education/themes/leading-the-international-agenda/ education-for-sustainable-development (accessed II February 2013). 
change from an institutional perspective. This level of analysis is important if we are to consider more systemic change within business education and more widely. The paper, then, draws together insights from the experience of organisational change that arose from the school's efforts to define ESD, and review and amend its curriculum and modes of teaching and learning.

The school sought to bring about change through a consultative process designed to make ESD an explicit dimension of existing and emergent curricula. In this particular case, ESD champions (called Academic Pioneers) were used as the primary change agents, supported by and working with an internal working group whose members were drawn from across the school. The case reveals that change can incorporate, paradoxically, both elements of a top-down and an emergent strategy that resonates with elements of life-cycle, teleological and dialectic frames for process change (Van de Ven and Poole i995). The case also highlights some tensions between radical-reorientation and incrementalconvergence approaches (Tushman and Romanelli I985) and offers some significant insights into the role of individuals as agents and actors of institutional change (see, for example, Lamberg and Pajunen 2010). A significant finding of this paper relates to the need for academic integrity (e.g. freedom to teach and research), which fits with Pring's (2002) exhortation for educators to regain confidence in their aims and curriculum. A lack of consensus about what constitutes sustainable development (SD) (cf. Okoye 2009) reveals a tension between those wishing to have a 'workable definition' of SD and those who see the need to permit a variety of approaches among the academic community. Taking account of these issues, the paper can be of relevance to policy-makers who promote ESD, managers who are to implement ESD policies and finally those who adopt ESD in operations (or deliver ESD in their practices). What emerges from the study is that the uptake of ESD can be successfully supported by an approach that enables academics to adopt ESD in a way that supports their existing contribution.

\section{Literature review: Sustainability in business education}

While it has been a topic of interest for much longer, research concerning teaching sustainability (or sustainable development) at business schools has had more particular focus through the developments of business ethics teaching and later corporate social responsibility teaching that had their roots in the late I980s (cf. Moore 2004; Christensen et al. 2007). Within business schools in particular, in recent years, the topic of sustainability has seen significant take up yet it still is seen 'as a relative "newcomer" to the MBA curriculum' (Christensen et al. 2007: 352). This surge in interest in sustainability has been tied to calls for business schools to educate more socially responsible and ethically aware graduates as a result of the perceived contributions of conventional business education to corporate failures (Mintzberg 2004). During this period, it can be said that teaching of business ethics and sustainability in business schools was 
a response to both local and global concerns. For the former, the need to educate more ethical professionals and leaders for the prevention of malpractice at the local level; and, for the latter, introducing CSR to promote better societal links across borders and sustainability to meet the urgency of issues surrounding global environmental and social patterns. In all cases the complexity and interdependence of actors within the business environment are now being recognised.

Ethics, and by inference sustainability, education, therefore is considered, 'to be the responsibility of many entities, [yet] organisations typically look to college education for the ethical development of potential employees' (Godsey 2007: 55). The UN Global Compact-Accenture CEO study (20I0), 'A New Era of Sustainability', firmly indicates corporations hold such expectations. The survey found that $93 \%$ of the 766 CEOs surveyed considered sustainability to be critical to the future success of their companies, with education being expected to provide business leaders with the capability to handle issues of sustainability. Thus, reflecting on observations by Pfeffer and Fong (2004), Cornelius et al. (2007: II8) note how business schools are seen to 'have responsibility to provide practitioners with training in the basics of ethics...which would ideally lead to an informed workplace and act as a catalyst to stimulate socially and ethically grounded corporate activities and programmes'.

The interest in sustainability education has led to the investigation of rationales for higher education institutions (HEIs) to implement ESD, explored in terms of internal and external drivers. As noted above, external drivers often come from HEIs' stakeholders for ESD. This has led to research into perceptions of future employees and students (e.g. McCourt-Larres and Mulgrew 2009) and the views of accreditation/regulatory bodies (e.g. Moore 2004). In recent years, HEI accreditation bodies have made greater effort to promote the incorporation of SD-related content into formal curricula. Such initiatives stem from global, regional and national bodies, for example the Principles for Responsible Management Education (PRME), Global Foundation for Management Education (GFME), European Academy of Business in Society (EABIS), Association to Advance Collegiate Schools of Business (AACSB) and Association of Business Schools (ABS).

The most noticeable internal driver is perhaps altruism, which leads to the championing of sustainability within their business operation (e.g. Atakan and Eker 2007). Another internal driver, closely related to responding to external factors, is the need to gain competitive advantage in the education market, and thus schools need to offer and update their unique selling point and/or innovative programmes. From this point of view, teaching SD appears to be a response to market demands. Many schools and departments - in the UK and elsewherehave at least incorporated sustainability-related materials in their programmes; a trend marked, for example, by 'Beyond Grey Pinstripes' (a survey conducted by the Aspen Institute Centre for Business Education). This survey provides an alternative ranking of business schools to indicate innovative full-time MBA programmes that lead the way in the integration of issues relating to social and environmental stewardship at curriculum level. Visibility in such a ranking of social and environmental stewardship is expected to be advantageous. 
Another stream of research concerning ESD identifies current practices. The focus has been to investigate the prevalence and trends for the inclusion of subjects such as ethics, CSR and sustainability, as part of programmes or modules. Such studies have been conducted in the global (e.g. Christensen et al. 2007-the top 50 global business schools), regional (e.g. Matten and Moon 2004-European business schools) and local contexts (e.g. Fernández and Sanjuán 2010-business schools in Spain).

The third stream of research is concerned with operational issues of ESD implementation. There are two areas of concern: identifying what is taught (contents) and how it is taught (instructive methods). Of the former, the focus ranges from a holistic view of content selections (i.e. curriculum development and design; Macfarlane and Ottewill 2004) to the micro level (i.e. usefulness of adopting particular substantive and/or theoretical domains as part of ESD [e.g. virtues]; Cameron 2006). The latter area focuses on debates around the efficiency of teaching methods in delivering ESD and thus noting desired learning outcomes (e.g. Macfarlane 200I).

Both areas, however, often appear to overlap since deliverable contents can in turn inform a particular way of teaching and vice versa. For example, Kearins and Springett (2003) explored a pedagogical approach to ESD in business schools based in critical theory. This, they point out, can lead to the challenging of a number of basic, underlying precepts of management studies itself. Following the introduction of critical concepts (informing a 'critical skill-set') such as reflexivity, critique and social action/engagement and the view that 'management is a social construction imbued with political motives', they highlight the impact on 'teaching praxis' (Kearins and Springett 2003: I92). Most importantly, as Prasad and Caproni (I997: 284) suggest, 'critical theory is deeply committed to the emancipatory potential of management and organisations. Thus it is also deeply committed to understanding how the everyday practice of scholars, educators, students, managers, and workers advances and inhibits this potential'. Inevitably, an ideological shift such as this, and subsequent need to develop a critical skill-set, has an impact on the delivery style of teaching itself. Similarly, Kashyap et al. (2006: 366$)$ propose 'a pedagogical approach examining aspiration as well as consequentialist antecedents of socially responsible behaviour by firms', which requires a different style of enquiry and questioning, with the potential to open students up to a number of 'interesting and paradoxical conclusion[s]' (Kashyap et al. 2006: 374; emphasis added). While the authors do not make the point explicit themselves, the implication would seem clear that a shift in content from 'cut-and-run strategies of firms' to 'longterm adherence to responsive strategies' (Kashyap et al. 2006: 374) corresponds to a shift towards a more open-ended style of enquiry and examination in and outside the classroom.

Last, but not least important, there is a small but growing body of research investigating the organisational process of ESD policy development and implementation. To date, there are a relatively small number of studies which discuss the entire process of ESD policy development and implementation in depth (e.g. 
a study on integration of environmental sustainability issues into a Master's programme in Finland by Pesonen 2003). It can be noted that the process of implementation remains a challenge; 'integration [of ESD] continues to be an elusive state for many programs' (Christensen et al. 2007: 358). Thus, there is a need to properly investigate and understand this so-called 'elusive state'. Since there are many reasons now to teach ethics, CSR and sustainability (whether altruistic, strategic or tactical), the critical question remains: how do we successfully develop and implement ESD in one's school?

\section{Research approach: Process and institutional perspectives on change}

There is long-standing recognition among writers on organisations that adopting a process perspective adds significantly to our understanding of organisational change (Pettigrew I990; Van de Ven and Huber I990; Poole et al. 2000; Tsoukas and Chia 2002; Van de Ven and Poole 2005). Change process theorists are not looking to develop process theory, but rather understand the nature of the processes of change (Van de Ven and Poole i995, 2005; Tsoukas and Hatch 200I). Van de Ven and Poole (I995) argue that interaction between different explanations of process will inform a better understanding of organisational realities. Nonetheless, they also argue that a degree of integration between different perspectives is desirable and from a critical literature review, identify four 'families' of process models that have the potential to inform the research and practice of organisational change (Van de Ven and Sun 20II). As set out by Van de Ven and Poole (I995: 520-2I), these four families of process models are taken as follows as analytical frameworks for this study:

1. Life-cycle or regulated change. The mode of change is prescribed, acts on a single entity, and the change process is one in which the entity progresses through a necessary, programmed and known in advance sequence of stages

2. Evolution or competitive change. Change is prescribed, acts on multiple entities and occurs through a repetitive sequence of variation, selection and retention events in a population

3. Dialectic or conflictive change. The mode of change is constructive, acts on multiple entities and occurs through conflict between opposing forces and interest groups. The process of change seeks to reconcile conflicting points of view

4. Teleology or planned change. Change is constructive, acts on a single entity and is focused on reaching an envisioned and known goal or end-state and occurs through an emergent and socially defined process of iterative implementation, evaluation and modification moving towards that goal 
The discussion section below explores the extent to which the ESD change project conforms to one or more of these models of change.

When considering a change process, such as the implementation of ESD, it cannot be divorced from its institutional context. Discussions of large-scale institutional change tend to focus on the challenges of trying to enact such change (see, for an example, Hafsi and Tian 2005) and recognise the constraints imposed by size, complexity, bureaucracy and formality on organisations seeking to enact change (North I990; Mezias and Glynn I993). However, in looking to go beyond the reasons for the failure of organisations to enact change, researchers have differentiated two levels of change. Tushman and Romanelli (I985) label these as 'radical-reorientation' and 'incremental-convergence'. The latter represents more adaptive changes focused typically on improving or developing known systems and processes, while a radical-reorientation represents a more fundamental shift with the adoption of new or novel systems, processes or practices. Researchers suggest that radical change in large organisations is difficult when compared with undertaking more incremental change and much change literature is concerned with enabling institutions to undertake large-scale radical change more effectively (Mezias and Glynn I993; Beer and Eisenstat 1996). As part of the discussion below, the institution's impact on the change is considered and the extent to which ESD represents a radical or incremental change is addressed.

Another issue in understanding change from an institutional perspective is the role of agents or individual actors in undertaking such change. The role of agents in institutional change is much debated (North I990; Selznick I996). One significant stream of thought argues that institutions act as significant restraints on an individual agent's ability to effect change (Hodgson 2007), while others (e.g. Lamberg and Pajunen 20I0) argue that individuals can potentially act as agents of institutional change and can influence the extent to which change is radical or incremental. Clemens and Cook (I999) suggest that agents can act through an institution's structure to stabilise more radical changes and contribute to a more incremental change outcome. The role and impact of agents in change is, therefore, also addressed below.

Recognising the failures of organisations to develop the capabilities needed to enact change (an issue still recognised; see for example Dixon et al. 20I0), Beer and Eisenstat (1996) identify, from extant research, three key principles that should inform effective change and proceed by demonstrating, through an action research project focused on improving an organisation's capacity to undertake effective change, that these principles have the potential to improve an organisation's long-term capability for change. The three principles are (Beer and Eisenstat 1996: 598-99):

1. The change process should be systemic. Beer and Eisenstat (I996) identify the need to ensure alignment and fit between the key elements of an organisation's 'design'

2. The change process should encourage the open discussion of barriers to effective strategy and adaptation. In this respect the resistance that often 
results from politics and defensive routines and typifies many organisational change interventions (Argyris I990) needs to be avoided. Unless there is effective and open discussion of a common vision and shared diagnosis of problems to ensure coherent interventions then change is highly likely to falter (Beer and Eisenstat 1996; Spicer 20II)

3. The change process should develop a partnership among all relevant stakeholders. Beer and Eisenstat (1996) highlight the importance of mutual influences and adjustments needed between stakeholders to enact change and highlight managers' limited ability and inclination to develop genuine partnership as a critical barrier in enacting a successful partnership approach

Beer and Eisenstat (1996: 599) suggest that 'these principles...despite their plausibility and their research support, are rarely reflected in actual intervention practice'. Our aim therefore is to analyse whether the change presented below evidences these principles effectively. A depiction of the change in line with this aim is provided in the section that follows.

\section{Methodology}

The purpose of this research is to develop a narrative description of ESD implementation within the business school at the University of Bradford. In line with the process theory perspective for understanding change adopted, following Van de Ven and Poole (2005), this research adopts an approach that follows Pentland's (1999) five narrative principles identified for effective explanations of the progression of events. Applied to the specifics of the study being addressed here, these are:

1. Adefined period of time that defines narrative of the change being addressed. In this case this is the formal funded period of the university's ESD programme which lasted for three years

2. Focal actors on whom the narrative rests. Here the focus is on the academic staff at the school and their responses to and views of the ESD initiative, as they are the actors tasked with implementing and making decisions in response to ESD

3. An identifiable narrative voice reflecting a specific point of view. The dominant voice here is that of the major agents of change at the school level, the Academic Pioneers, who are also two of this paper's authors

4. Awareness of context and its impact. As indicated when identifying with an institutional perspective on change above, while the focus of the study is on change at the school level, in its description below, the impact and implications of events and decisions across the wider institution that are necessary for understanding this change are addressed 
5. An evaluative frame of reference against which the details of the experience can be judged. The evaluative frame of reference employed here is Beer and Eisenstat's (I996) guidelines for effective strategy implementation and organisational adaptation which form the basis of the discussion of this change, as outlined in the previous section

The construction of this narrative draws on data from a range of sources. All authors acted as participant observers and were heavily involved in the school's implementation of ESD as members of the ESD Working Group in this school (two as change agents responsible for implementation of ESD), and the output from this group (minutes and reports) was available for review in the development of the narrative below. Two particular activities that generated reports were significant in developing the narrative below:

- A staff consultation exercise concerning ESD was undertaken by members of the working group. ESD was discussed with a range of academic members of staff through subject group meetings, and in addition I2 one-to-one interviews were undertaken by the Academic Pioneers with individual staff members. The following two questions were discussed at either group meetings or interviews: I) what is going on in your modules in relation to education for sustainable development? and 2) could you describe a particular example of your teaching on sustainable development? The purpose of the discussions was to give academic members of staff an opportunity to think about ESD in their subject context and to prepare them to respond to a follow-up questionnaire

The follow-up questionnaire aimed to identify perceived appropriate levels and modes of ESD delivery and to identify input and support that the members would require for ESD delivery. The questionnaire (full detail in the Appendix) was distributed to all the academic members of staff; 58 $(68.2 \%)$ responses were returned including 55 (64.7\%) usable responses out of 85 (I00\%). The numbers of the respondents by rank are: professor/ reader $=\mathrm{I} 4$; senior lecturer $=\mathrm{I} 8$; lecturer $=25$; other $=\mathrm{I}$

It should be recognised that these data sources were collected primarily for the process of ESD implementation and hence should be viewed as secondary data sources for the purposes of this paper. The direct involvement of all the paper's authors in this process is also a potential limitation, but this is hopefully somewhat mitigated by the fact that the narrative findings below represent a consensus on the changes as they developed agreed by all the authors.

\section{Findings: Implementing ESD in the business school}

The development of ESD at the University of Bradford's Business School can be examined through the lens of Beer and Eisenstat's (I996) principles of effective strategy implementation and organisational adaptation. What becomes 
apparent is that while change can be described as systemic, with top-down directives, it is also informed by a commitment to open discussion and engagement with stakeholders.

\section{Systemic change}

The change process was strategic in that ESD was identified by both the university and the school as part of their vision and mission and integral to the growth and 'competitive' positioning of the institution. In understanding the impact of this strategy on the institution, three key aspects of the organisation's system can be identified. The first is leadership, senior university administration and their role in supporting ESD. The second is the placement of 'change agents' within the school who acted to influence the elements of the organisation at this level. The third is the performance indicators used to assess the uptake and impact of ESD.

ESD at this business school began with the university's commitment to student learning about sustainable development, but the underpinning university-wide project was funded through the UK's central state funding body, Higher Education for Central England. The overall fund was worth $£_{3}$.I million (approximately US\$6.2 million at the time the project started), with half a million pounds (approximately US\$I million) allocated to six schools for the embedding of ESD into the formal curriculum. The Pro-Vice-Chancellor for Learning and Teaching outlined the adopted approach as one seeking 'to develop discipline-led, student relevant and locally meaningful ESD developments within and under the overall UNESCO framework'; ${ }^{2}$ an approach that was thought 'to address sustainable development and ESD development within its own specific context and school culture has, to date, been successful in terms of gaining academic support' (memo to deans of school). Thus, the project was initiated by the university's senior administration and underpinned by three years of financial support.

There were three 'agents' critical to the formalisation of ESD within the School of Management: ESD champions, or 'Academic Pioneers'; the Associate Dean for Learning and Teaching; and an ESD Working Group. The Academic Pioneer role was undertaken by established academics, in possession of current and regular experience of face-to-face delivery of teaching. Their task was to liaise with colleagues throughout the school to gain an in-depth picture of current provision and to champion the embedding of ESD across the curriculum. From the outset, they worked closely with one of the Associate Deans for Learning and Teaching, who played an important role to bring together the necessary ingredients for institutional change in relation to the school's

2 The framework to which this refers is the UNESCO articulation of ESD employed at the beginning of this paper which describes and forms part of the UN's Decade of ESD agenda (running until 20I4). More details can be found at: www.unesco.org/new/en/education/ themes/leading-the-international-agenda/education-for-sustainable-development (accessed ir February 2013). 
management team for policy development. The establishment of a working group at the school-with the brief of assisting the implementation of ESD practices-was considered strategically important to the further development of ESD's implementation. The Working Group consisted of representatives from the six subject groups, the two Academic Pioneers and the Associate Dean and met on a six-week cycle.

Members contributed to facilitating a school-wide consultation (on pedagogical and operational issues) and formulating policies. Throughout its duration and at its summation, the project was measured against a 'deliverables matrix' by the working group and the senior management of the school and university. The 'deliverables matrix' was developed by the Academic Pioneers (in consultation with the ESD working group), aligning university and school aims with roles of responsibility and outputs or actions. Through this mechanism, the ESD project could be assessed for its impact in a number of specified ways, all of which needed to be assessed for financial accountability.

\section{Open discussion of barriers}

The Academic Pioneers conducted an audit of ESD practices within the School of Management. The following keywords were identified and used as a tool to open up discussions and consider different points of view: sustainable development (SD), dignitary and human rights (social and economic) justice, intergenerational responsibility (future generations), ecosystems (protection, restoration) and cultural diversity (culture of tolerance, non-violence and peace). The review investigated the following key areas:

ESD content in course programme documentation

- Existing ESD delivery within the School of Management

The opportunities for, and the issues surrounding, the current and future delivery of ESD in the School of Management

Alongside content analysis of programme documentation (module descriptors, programme specifications and programme brochures), information was gained through email survey of the academic staff. In addition, semi-structured interviews were conducted with I2 members of academic staff involved in the delivery of the programmes in the School of Management. These interviews helped gain a more in-depth understanding of issues related to ESD implementations as well as details of good practice in operation. The emerging issues could be grouped into three main themes. The first concerned implementation and highlighted time constraints on the part of teaching staff along with their perceived lack of expertise about SD. The second concerned policy development, specifically the need for a coherent strategy at the school level. Interviewees were highly aware, for example, of stakeholders benchmarking exercises and competitors' activities concerning ESD. It was thought that competition would be a highly motivating factor for the school to adopt ESD. 
One interviewee expressed the view that the school should not be a follower in the delivery of ESD, but 'should get in [to the area] at the early stage'. The third theme concerned attitudes towards ESD. In general, there was low regard for university initiatives of this kind. One respondent asked: '...is this another initiative like employability, internationalisation etc., is this just another fad?’ Another held the view that the issues of ethics and responsibility are part of common practice for educators, so questioned the need to make them a special case at that particular point in time.

The interview process helped clarify how the development of an SD curriculum would need to be coordinated for all the degree programmes. Accordingly, various measures were taken in an attempt to embed ESD further within the school. First, ESD was integrated into the school's learning, teaching and assessment strategy in order to formalise development of ESD (as specified in the deliverables matrix). This, to a degree, legitimised ESD practices, with support from senior administration at both school and university levels critical to the institutionalisation of ESD. Second, a statement for ESD was generated within the school. A working group was then established to develop policy and consider pedagogical approaches to ESD implementation. It facilitated a critical school-wide consultation as a vehicle for formal and informal discussions, helping to build wider support across the school. In due course, the working group developed into a highly effective focal point for ESD implementation within the school.

The school-wide consultation exercise helped to give all academic staff an opportunity to comment on ESD in their subject context and prepared all participants to respond to a questionnaire. The follow-up questionnaire (55 usable responses were obtained representing 64.7\%) was designed to identify the appropriate level and instructive methods for ESD, the necessary support for ESD implementation, and any other concerns. Tables I-4 show that most respondents thought SD should be taught, although most of the staff argued that ESD-related modules should not be compulsory for students. However, a proposal for offering a stand-alone module on SD (i.e. an explicit instance of ESD delivery) was supported by staff particularly with respect to final year undergraduate and postgraduate levels. Yet, the need to integrate SD into existing modules was recognised at all levels (around 80\% of the respondents).

Table 1 Appropriate level/degree to teach sustainable development

\begin{tabular}{lllll}
\hline & Yes (valid \%) & No (valid \%) & Total & No responses \\
\hline Level 1 & $33(60.0)$ & $22(40.0)$ & 55 & 3 \\
Level 2 & $34(61.8)$ & $21(38.2)$ & 55 & 3 \\
Level 3 & $51(92.7)$ & $4(7.3)$ & 55 & 3 \\
MSc & $50(90.9)$ & $5(9.1)$ & 55 & 3 \\
MBA & $48(87.3)$ & $7(12.7)$ & 55 & 3 \\
\hline
\end{tabular}


Table 2 Sustainable development as compulsory or option

\begin{tabular}{lllll}
\hline & Compulsory (valid \%) & Option (valid \%) & Total & No responses \\
\hline Level 1 & $11(37.9)$ & $18(62.1)$ & 29 & 29 \\
Level 2 & $8(25.8)$ & $23(74.2)$ & 31 & 27 \\
Level 3 & $15(31.9)$ & $32(68.1)$ & 47 & 11 \\
MSc & $18(37.5)$ & $30(62.5)$ & 48 & 10 \\
MBA & $19(39.6)$ & $29(60.4)$ & 48 & 10 \\
\hline
\end{tabular}

Table 3 Sustainable development to be taught as stand-alone module

\begin{tabular}{lllll}
\hline & Yes (valid \%) & No (valid \%) & Total & No responses \\
\hline Level 1 & $10(25.0)$ & $30(75.0)$ & 40 & 18 \\
Level 2 & $10(24.4)$ & $31(75.6)$ & 41 & 17 \\
Level 3 & $28(54.9)$ & $23(45.1)$ & 51 & 7 \\
MSc & $33(67.3)$ & $16(32.7)$ & 49 & 9 \\
MBA & $30(62.5)$ & $18(37.5)$ & 48 & 10 \\
\hline
\end{tabular}

Table 4 Sustainable development to be integrated into modules

\begin{tabular}{lllll}
\hline & Yes (valid \%) & No (valid \%) & Total & No responses \\
\hline Level 1 & $35(74.5)$ & $12(25.5)$ & 47 & 11 \\
Level 2 & $36(80.0)$ & $9(20.0)$ & 45 & 13 \\
Level 3 & $46(85.2)$ & $8(14.8)$ & 54 & 4 \\
MSc & $42(80.8)$ & $10(19.0)$ & 52 & 6 \\
MBA & $44(83.0)$ & $9(17.0)$ & 53 & 5 \\
\hline
\end{tabular}

In response to the question of whether 'interdisciplinary input is necessary for SD curriculum development', the majority of respondents $(43 ; 8$ I.I\%) thought interdisciplinary modules on SD should be developed. This stems from the understanding that sustainability is interdisciplinary in nature. Collaboration in curriculum development across the disciplines was seen as essential to prevent any overlapping in ESD teaching. To the question of whether 'the school should have specialists who teach SD', 32 respondents (60.4\%) thought that the school should have SD specialists, while 2I (39.6\%) claimed that this need not be the case. Among those who found no need for specialists, there is a strong view that academic members should be able to teach or are teaching SD issues because these issues are relevant to current practices and naturally blended into the subject they teach. The respondents were also asked to provide comments with regard to 'what sort of support they would like to have if they were to teach SD'. Table 5 summarises the points raised. 
1. A rationale for teaching SD needs to be provided along with:

A definition of what constitutes SD in the school context School policies and guidelines articulating appropriate teaching styles

2. Training and staff development (e.g. conferences and workshops) would be desirable in order to:

Understand how SD issues relate to their modules (i.e. in-depth knowledge)

Gain skills in how SD can be taught (i.e. teaching methods)

Check whether key aspects of SD are appropriately incorporated into the module (i.e. a comprehensive and holistic approach by the school)

Make sure that tutors have consistent understanding on the subject

(i.e. consistency in delivery)

3. Material support would also be welcome in the form of:

Relevant academic journals

Case studies

Real examples of lectures and tutorials which embody the SD agenda

4. Access to industrial applications (i.e. business engagement)

5. Cross-disciplinary support and collaboration for teaching

6. Financial support to invite guest lecturers

7. Good research components to feed into teaching

Respondents were also asked to raise 'any concerns with regard to the implementation of ESD'. Of particular significance, some respondents indicated that implementing ESD would/could be in conflict with academic integrity. For example, the following views were expressed:

Implementing ESD might amount to the advocacy or promotion of particular ideologies [which] would be counter-productive, since such efforts may be viewed as propaganda.

SD issues should be integrated into everything we teach and is just a part of good ethical teaching practice. Giving it a separate label and specialist teachers mystifies it and makes it less accessible rather than more so.

There are concerns about the implications for freedom of speech and thought (academic freedom) if ESD were to be foisted on teaching staff.

It can be seen from the range of views and information gathered that both the university-wide forum attended by the Academic Pioneers (chaired by the Director for ESD) and the local School of Management Working Group gave the space for open discussion of the barriers faced during the implementation process, and as such were critical to the identification of obstacles and ways to overcome them.

\section{Partnership among stakeholders}

As is evident from the above, various opportunities were created to work in partnership with several stakeholders of the school. Agreement over the place and purpose of ESD within the school and its curriculum was ultimately only achieved because of the negotiated understanding of ESD developed through 
working with a wide cross-section of academic staff. In addition, the involvement of external stakeholders was achieved through a variety of means, including an ESD seminar series with external speakers, working with alumni, supporting researchers interested in ESD from other institutions and communicating with professional and accreditation bodies such as AACSB and PRME.

\section{Discussion}

While the school's (and ultimately the university's) senior management judged ESD implementation to be successful, the barriers and challenges to implementation at an operational level need to be recognised. Table 5 summarises the findings in this regard, and many of the factors identified by Velazquez et al. (2005: 385) were identified as influencing the uptake of ESD. Significant of these was that, after the project funding period came to an end, any further development of ESD consequently poses a challenge. However, at the end of the ESD change programme, the school obtained a membership of PRME, and established a committee to consider ESD. The school therefore has a vehicle for ongoing ESD development. ESD is no longer a new initiative but part of its ongoing operations; ESD is evidenced at module and programme levels, and in the school's overall strategy and learning, teaching and assessment strategy. The implications of this change are explored below.

It seems evident that the three principles of effective change identified by Beer and Eisenstat (I996) were critical together in ensuring the uptake of ESD. Of these, it is the second principle (open discussion of barriers) that appeared most significant in guiding the change. Academic Pioneers and their engagement with faculty through interviews, the working group and in the school-wide consultation provided opportunities for stakeholders to work through their concerns with ESD and its implementation. The dialogue created provided space for faculty to develop their own sense of the place of ESD in their practice. The exact nature of ESD was, within the frameworks outlined by the institution, individually determined and faculty came to adjust their practices in response to the initiative. This suggests that the open discussion of barriers was critical in developing the third principle, partnership among stakeholders, although the levels of partnership were limited (and hence overall agreement on specific ESD requirements was not required).

The role of Academic Pioneers was also critical in supporting Beer and Eisenstat's (I996) first principle (that the change process was systematic), through their programme of engagement with staff, to coordinate the change across the school, and focused on identifying a fit between outcomes at the school level and the university strategy for ESD. This was enabled by the deliverables matrix which provided operational foci for ESD that linked back to overall strategic goals. All this together suggests that Beer and Eisenstat's (I996) principles should be seen as mutually reinforcing. The systematic approach (ensuring that ESD impacted across the organisation and its differential impacts on different organisational 
elements) was significant in allowing local development and adoption of ESD in schools, and this allowed open discussion of barriers to implementation that cemented the partnerships between stakeholders at the school.

This ESD change process seems to combine three of Van de Ven and Poole's (I995) frameworks: life-cycle, teleological and dialectic approaches to change. These can be seen as explaining the nature of the change in different ways as the perspective, focus and key drivers of the change shift. Van de Ven and Poole's (I995) frameworks can therefore be seen as lenses through which we can focus on different aspects of this overall change process, and hence the explanation and action of this change can be seen as being influenced by the stakeholder perspective on which we focus. Table 6 describes three such perspectives, labelled as three change stages-initiation, implementation and integrationand identifies the key aspects of each. These differences of explanation seem to suggest that the process change frameworks provided by Van de Ven and Poole (I995) are complementary rather than distinct. The position, level and perspective of the actors in relation to the change affect how it is enacted, perceived and applied. Here the process of ESD implementation is explained and accommodated very differently depending on whether you are the instigator of the change (senior management), its agent (Academic Pioneers) or recipients (academic staff). However, these differences should not be perceived as elements of the process itself. The change did not necessarily happen in a linear fashion, proceeding through these perspectives as stages. These explanations are best viewed as differing interpretations of the nature of the change that are informed by the concerns of actors at a certain level, and the implications of each are outlined below.

Table 6 Education for sustainable development as a process of change

\begin{tabular}{llll}
\hline & \multicolumn{2}{l}{ Change stage } & \\
\cline { 2 - 4 } & Initiation & Implementation & Integration \\
\hline $\begin{array}{l}\text { Framework (Van de } \\
\text { Ven and Poole 1995) }\end{array}$ & $\begin{array}{l}\text { Life-cycle/ } \\
\text { regulated }\end{array}$ & $\begin{array}{l}\text { Teleological/ } \\
\text { planned }\end{array}$ & $\begin{array}{l}\text { Dialectic/ } \\
\text { conflictive }\end{array}$ \\
\hline $\begin{array}{l}\text { Change impacts } \\
\text { through }\end{array}$ & Institution & Change agents & $\begin{array}{l}\text { Individual } \\
\text { sensemaking }\end{array}$ \\
\hline Level of focus & University & $\begin{array}{l}\text { School (as } \\
\text { organisational unit) }\end{array}$ & $\begin{array}{l}\text { Faculty (as } \\
\text { individuals) }\end{array}$ \\
\hline Key actors & $\begin{array}{l}\text { Senior } \\
\text { management } \\
\text { (change sponsors) }\end{array}$ & $\begin{array}{l}\text { Academic Pioneers } \\
\text { (change agents) }\end{array}$ & $\begin{array}{l}\text { Academic } \\
\text { staff (change } \\
\text { recipients) }\end{array}$ \\
\hline
\end{tabular}

\section{Initiation of regulated change}

On initiation (perspective I in Table 6), the change seems to have been defined by the institution (university senior management) in a way that would subscribe most closely to the life-cycle or regulated approach to change. The implied 
metaphor here is that the focus of organisational leadership, the de facto sponsors of this change, was on providing the direction for 'organisational growth'. The university can therefore be seen as viewing this change as a prescribed programme of activities and actions (with definable resources in terms of time and funding), impacting on a single entity (the university as a whole) that would lead to a defined and knowable end-point (ESD implementation). The focus of the change for senior management was on the development and communication of ESD as a policy objective for the institution as a whole.

Identifying the change as being spread through the organisation and thereby its impact being adapted and negotiated at a local level, best characterises what Tushman and Romanelli (I985) labelled 'incremental-convergence'; changes were largely incremental developments in the overall educational experience that emerged as academics sought to make sense of ESD in their own teaching and seek a fit (convergence) between their teaching and the requirements of ESD. Balogun (2006: 29) gives an example of a 'textbook top-down approach to change' but similarly highlights how many of the outcomes of such change are emergent or unintended as the recipients of change make sense of the senior management initiatives.

Seeing ESD as an emergent incremental change is at odds with the topdown, radical perspective on change that ESD represented in terms of its rhetoric for the organisation. The university saw this as a programme aimed at making (relatively) radical change and its drive came (at least perceptually for the majority of academics) from the top of the organisation. The prevailing view in institutional theory is that such changes are limited in their success by the complexity and bureaucracy of the organisations on which they act (North I990; Mezias and Glynn I993; Hafsi and Tian 2005). However, we have here a strategic change for the institution that has been brought about successfully. It appears that this radical change was built from a series of more incremental, emergent responses to ESD. Plowman et al. (2007) provide an example of how (in their case unintended) radical change emerged from more incremental changes as a church congregation sought to re-engage with the local community in a number of small and discrete ways (starting with providing breakfast for the local homeless who were previously seen as a nuisance by many churchgoers). It appears that we have here another case in which an intended radical change was built emergently from the incremental actions of its participants. This may suggest a reconciliation of incremental and radical approaches to change and might show how radical change can be created in institutions through the coordination and amplification of incremental changes across the organisation.

\section{Implementation with planned change}

On implementation (perspective 2 in Table 6) at the school level, approaches to the change might more readily be reconciled with a teleological or planned approach. One way of interpreting the deliverables matrix is as a set of goals 
(that align to the superordinate goal of ESD implementation) against which Academic Pioneers constructed a series of activities with multiple entities (subject groups and individual academics) to encourage the uptake of ESD. Practically the focus was on the dissemination and interpretation of ESD policy requirements. ESD can therefore be explained as a planned series of activities that were aimed at building (constructing socially) consensus around a set of aims that all led to the desired organisational outcome. The growth of ESD was supported by its planned activities and the teleological approach to change can be seen as enabling the process of development along life-cycle lines.

It appears here that the change agents (Academic Pioneers) played a key role in supporting the implementation of the change. The role of agents in institutional change is a matter of debate (Selznick I996) and the prevailing view tends to suggest that institutions act to limit agents' abilities to enact change (Hodgson 2007). The experience here, however, better supports arguments from Clemens and Cook (I999) and Lamberg and Pajunen (2010) that agents can influence change in institutions. Academic Pioneers played a crucial role in spreading the change across the school and interpreting that change for stakeholders, supporting them in their sensemaking in relation to the change. For the institution they acted to coordinate, summarise and publicise ESD's impacts, and integrate the incremental changes together to provide the 'overall picture' of radical change. This reinforces the arguments of those who suggest that the contributions of dedicated change agents are critical to the likely success of change (Caldwell 2003; Saka 2003). Here we reach a particular conception of the change agent's role as providing coordination for changes across an institution with a view to providing an overall coherent picture of change and supporting the translation and assimilation of that change at the local level.

\section{Integration through dialectic change}

If we shift perspective to the integration (perspective 3 in Table 6) or uptake of the change, there is scope for a third framework to come to the fore. In terms of its influence at the individual level on the academic faculty and subject groups, the change can be mapped onto the dialectic or conflictive approach to change. The process of involvement of stakeholders and their discussions of the meaning of ESD for them ultimately led to synthesis between those individuals' and groups' understandings of ESD and their approaches to teaching and learning. This emerged through the confrontation of conflicts raised in this discussion. Faculty were tasked with the action of the policy and were supported in integrating ESD with their practice. This discussion, an activity planned and supported by the Academic Pioneers, ultimately led to the university's aims for ESD being realised.

It is significant that, for ESD to have been successful, its integration into individual's practice is something that had to be negotiated. There is therefore a significant role here for sensemaking (Weick I995), with the processes of dialectic enquiry leading academics to make sense of the organisationally ascribed 
values of ESD for their own teaching practice. Significantly, Weick (I995: I8) sees sensemaking as being 'grounded in identity construction' and identifies the process of confirming one's self as significant in intentional sensemaking. This aligns the development of ESD described here with the principles of effective sustainability learning described by Shrivastava (2010), who argues that sustainability education requires more than a cognitive understanding of its principles, but rather a sustained commitment and engagement from educators (and students) and that this is only likely if the ideas espoused are meaningful to and significant for educators.

ESD was implemented with a minimum level of presumption about what SD means. As a consequence the debates (in the dialectic frame) were not around the validity of prescription but rather centred on the place and appropriateness of SD across the curriculum. This afforded individual staff space (as evidenced in the interviews undertaken) to make their own judgements of the relevance of ESD to them, and their teaching and practice, and adopt it in ways that supported rather than conflicted with their own values and approach. Here ESD as a result was largely integrated into existing courses but the institutional demands for this meant that this integration came across curricula. Rusinko (2010) suggests that such approaches are appropriate where institutions see sustainability as a priority and where faculty are motivated to make such changes, and interestingly the experience here does suggest that motivated faculty can support widespread uptake of sustainability issues within a curriculum that requires minimal administrative and management resource, but this creates an ongoing challenge of ensuring continuing faculty commitment and consistency of delivery with respect to ESD.

Another consequence of the way ESD was implemented here is that it supports demands for faculty to regain confidence in their role as educators (Pring 2002), and suggests that senior management needs to create a supportive environment for faculty to maintain (or regain) that confidence and professional integrity in teaching SD. Its effective implementation also supports Scott and Gough's (2007: II3) arguments that we should avoid becoming 'uncritical repositories of present unconventional wisdom' and developing generic modules and teaching and learning frameworks for ESD. Instead: 'the protection that some universities offer their staff and students through a policy enabling and encouraging, but not prescribing, internal developments can be seen as a valuable safeguard: a barrier to defend rather than to discard' (Scott and Gough 2007: II3).

We therefore argue that, linked to the above discussion and the arguments made by Pring (2002), a factor contributing to the integration of the ESD change was the integrity of academics involved in this process. It is our conception that integrity is important to academics in defining themselves (as it is for many professionals) and hence change which is seen to reinforce personal integrity is likely to be successful. Significantly the non-prescriptive process of ESD implementation that emerged here allowed faculty space to understand and negotiate the impact of ESD on their own teaching and time to reflect on 
ESD's implications in their subject areas. This process of sensemaking provided faculty with the opportunity to incorporate ESD in the way best suited to them and hence ultimately supported their academic integrity. Petrick (2OII) links integrity with values and differentiates between intrinsic values (that reside solely within the individual) and instrumental values that: 'can be treated as an intangible strategic asset that individuals and collectives can responsibly manage to enhance their domestic and global reputational competitive advantage' (Petrick 20II: 50).

Here the ESD change may have been successful, in part, because the decision of the institution to define a set of broad organisational instrumental values for ESD reinforced values that already existed at the individual intrinsic level and actually served to bring those intrinsic values into an explicit instrumental frame. In a similar vein, this process can be seen as connecting academics' values with those of the organisation in a way that does not conflict with their basic assumptions and suggests how this change may ultimately become embedded in the culture of the institution (Schein I984).

It seems potentially evident from the arguments above that change which supports individual integrity has potentially more legitimacy that that which does not. Reed (I999a) identifies legitimacy as a key element of Habermas's (I996) theory of law and democracy 'which is able to integrate moral, ethical and pragmatic discourses' (Reed I999a: 26). This argument suggests that for the policy of an institution (in Habermas's case the law created by a governing authority) to be seen as legitimate by those individuals it acts upon, it has to be subjected to 'communicative discourse' among those individual stakeholders through which any moral, ethical and pragmatic concerns can be addressed (Smith 2004). Furthermore, according to Reed (I999a), the direct role of formal institutions is secondary to the communicative discourse itself as it is this that leads to policy which provides useable guidance for practice. Significant for the experience here, Reed (I999b) identifies argumentation as a reflexive form of communicative discourse that allows stakeholders to explore the validity of the ideas presented to them. This links the life-cycle and dialectic approaches to change identified above. It was the communicative discourse of academics reflecting on the policy of ESD (a process of dialectic change) and largely finding it valid as it was supportive of their own integrity (values) that ultimately led to their willingness to adopt ESD (the institution's intended life-cycle change).

\section{Conclusion and implications}

The identification of initiation, implementation and integration as three stages of change within the experience of the development of ESD here can also potentially act as a framework to guide others seeking to develop ESD in their own institutions. Table 7 summarises the three stages identified from a practical rather than theoretical perspective and highlights the key activities to be 
undertaken at each of these stages. The presentation of these activities is not intended to suggest a linear process for completion of each of these in turn as it was the experience here that these activities and the three stages of change did interact and overlap with each other, but the time perspective is included to recognise that in the experience here the change began with initiation by the institution and progressed through implementation to integration. It is also significant that the majority of the actions for change lie at the implementation stage. Success here came from a largely devolved approach to change. With a clear purpose and agenda set by the university, change agents at the school level had the responsibility for enacting and implementing ESD in ways appropriate to their contexts. This led to significant adaptation of the policy to suit the school's own educational agendas. That adaptation ultimately encouraged individual faculty's uptake of the principles the institution wanted to develop. Educators adopting the advice this contains should do so with caution, however, as this is drawn from a single example of change in the business school of one university, the members of which were largely supportive of the principles of ESD. Other contexts and a more contentious response to ESD may require alternative actions.

Table 7 Agenda for developing education for sustainable development

\begin{tabular}{|c|c|c|c|}
\hline & \multicolumn{3}{|l|}{ Change stage } \\
\hline & Initiation & Implementation & Integration \\
\hline Level of focus & University as a whole & $\begin{array}{l}\text { School, department or } \\
\text { other meaningful unit }\end{array}$ & Individual faculty \\
\hline Key actors & $\begin{array}{l}\text { University senior } \\
\text { management }\end{array}$ & Change agents within units & Academic staff \\
\hline Key activities & $\begin{array}{l}\text { Set ESD agenda and policy: } \\
\text { provide vision and direction } \\
\text { Identify appropriate } \\
\text { reference points for } \\
\text { external benchmarking (e.g. } \\
\text { UNESCO; PRME) } \\
\text { Provide resources (time, } \\
\text { money, people) } \\
\text { Identify change agents }\end{array}$ & $\begin{array}{l}\text { Dissemination and } \\
\text { interpretation of policy and } \\
\text { adapt to local conditions } \\
\text { Identify unit level reference } \\
\text { points (e.g. AACSB; QUIS; } \\
\text { AMBA) } \\
\text { Undertake diagnosis and } \\
\text { analysis to understand } \\
\text { current situation with } \\
\text { respect to ESD } \\
\text { Define deliverables and } \\
\text { monitor progress against } \\
\text { these } \\
\text { Engage staff in open } \\
\text { discussion about ESD to } \\
\text { develop partnership } \\
\text { Coordinate, summarise and } \\
\text { publicise ESD's impact }\end{array}$ & $\begin{array}{l}\text { Understand impact } \\
\text { on own practice and } \\
\text { negotiate adapted } \\
\text { practice in light of } \\
\text { policy } \\
\text { Provide deliverables } \\
\text { Confirm academic } \\
\text { identity and integrity }\end{array}$ \\
\hline Time & & & \\
\hline
\end{tabular}


In addition, the findings of this study suggest a number of implications for policy-makers who promote ESD, managers who implement ESD and those who adopt and deliver ESD programmes, as well as being relevant, in part, to anyone seeking to enact large-scale organisational change. ESD ought to be an initiative that garners support from stakeholders in that, properly enacted, its principles seem supportive of individual academics' integrity and hence it should therefore be seen as valid by stakeholders across higher education institutions. Significant in this statement though is the phrase 'properly enacted'. Key among the findings is the recognition that the uptake of ESD (and by extension similar strategic changes) is influenced by the model of implementation employed. In this case, Beer and Eisenstat's (I996) guiding principles help define the mode of implementation; including adequate opportunity for discourse and discussion, partnership between stakeholders and flexibility in the implementation of ESD at the local level. Given the effective integration of ESD into the institution, it would seem reasonable to suggest future implementations (at least of a similar nature) would do well to explicitly follow key principles as laid out by Beer and Eisenstat (I996). In addition, a role for dedicated agents of change to act as champions for ESD and drivers of the process of implementation (as was the case with the Academic Pioneers here) should also be highlighted as significant in providing focus, direction and coordination for ESD activities.

The preceding discussion highlights a number of implications for further research. First, other studies should be undertaken to see if the identification of initiation, implementation and integration of stages in the development of ESD might be replicated. It is a limitation here that this study focuses on a single school and a single university context and greater support for this ESD development agenda would come from its being evidenced through other contexts. In addition, the positive impact of the Academic Pioneers suggests the importance of a role for determined agents coordinating 'change activities' within the institution. As this finding is at odds with conventional institutional perspectives on change (which suggest institutions act to limit the ability of agents to enact change; North I990; Mezias and Glynn I993), further investigation of the role and impact of change agents on institutions would be valuable. The findings also suggest that a more radical institutional change emerged from the incremental activities at the individual and school levels. Further detailed exploration of the potential complementary nature of radical and incremental change would therefore seem warranted. A number of other issues may also be worthy of further consideration. The example of change here indicated that the perspective of the actors affected the nature of explanation of process, with the university, Academic Pioneers and faculty perspectives all being linked to a different framework for understanding the change process (after Van de Ven and Poole i995). The nature of these differences and how they contribute to the emergent nature of organisational change also ought to be explored. Similarly, the roles of integrity and sensemaking and their links with the uptake of change and ethical approaches to and perspectives on change highlighted above would benefit from further investigation. Further consideration of exemplary change processes invoking Beer and Eisenstat's (I996) principles as being mutually 
reinforcing would also be of interest for scholars seeking to better understand the drivers of successful organisational change. Finally, research exploring the developing role of ESD in the business school curriculum should also continue.

We titled this paper 'Sustainable Change' for two reasons. First it is an example of change, regarding the introduction and embedding of the principles of sustainability into a HE institution and, particularly, a business school. Significantly, it is revealed that the effectiveness of this change was in large part enabled by the links between the principles of ESD and the values of academics across the school and hence the change was supportive of academics' personal and professional integrity. Nevertheless, a note of caution must be raised. While our assessment suggests there was genuine integration of ESD principles across the school, there remains the possibility that individual instances of engagement with ESD are superficial, only paying lip service to the institutional directive. The ongoing success of ESD will then be compromised if this is the case.

Thus, 'Sustainable Change' is also meant to describe an example of change that in its implementation suggests the process itself is sustainable. The change experience in this case suggests that the principles identified by Beer and Eisenstat (I996) were significant in effecting change and it was argued above that its effectiveness stems in large part from the discussion and debate around ESD led by the Academic Pioneers. This debate afforded individual academics the opportunity to negotiate the impact of ESD on their own practice and thereby accommodate it with their own values and integrity. We would suggest that this debate and the dialogue it created were essential to enacting this change and this has to be a continuing process. Change was studied here as a process not an outcome. Effective change is best conceptualised as a journey and in this vein ESD should itself be ongoing and long-term if its impact is truly to be judged as successful.

\section{References}

Accenture (20I0), 'A New Era of Sustainability: UN Global Compact-Accenture CEO Study 20I0', www.unglobalcompact.org/docs/news_events/8.I/UNGC_Accenture_CEO_Study_ 2010.pdf (accessed 26 July I3).

Argyris, C. (1990), Overcoming Organizational Defences, Allyn and Bacon, Boston, MA.

Atakan, M.G.S. and Eker, T. (2007), 'Corporate identity of a socially responsible university: a case from the Turkish higher education sector', Journal of Business Ethics, Vol. 76 No. I, pp. 55-68.

Balogun, J. (2006), 'Managing change: steering a course between intended strategies and unanticipated outcomes', Long Range Planning, Vol. 39, pp. 29-49.

Beer, M. and Eisenstat, R.A. (I996), 'Developing an organization capable of implementing strategy and learning', Human Relations, Vol. 49, pp. 597-6I9.

Caldwell, R. (2003), 'Models of change agency: a fourfold classification', British Journal of Management, Vol. I4, pp. I3I-42.

Cameron, K. (2006), 'Good or not bad: standards and ethics in management change', Academy of Management Learning and Education, Vol. 5 No. 3, pp. 317-23. 
Christensen, L.J., Peirce, E., Hartman, L.P., Hoffman, W.M. and Carrier, J. (2007), 'Ethics, CSR, and sustainability education in the Financial Times top 50 global business schools: baseline data and future research directions', Journal of Business Ethics, Vol. 73, pp. 347-68.

Clemens, E.S. and Cook, J.M. (I999), 'Politics and institutionalism: explaining durability and change', Annual Review of Sociology, Vol. 25, pp. 44I-66.

Cornelius, N., Wallace, J. and Tassabehji, R. (2007), 'An analysis of corporate social responsibility, corporate identity and ethics teaching in business schools', Journal of Business Ethics, Vol. 76 , pp. II7-35.

Dixon, S.E.A., Meyer, K.E. and Day, M. (20I0), 'Stages of organizational transformation in transition economies: a dynamic capabilities approach', Journal of Management Studies, Vol. 47, pp. 416-36.

Fernández, J.L.F. and Sanjuán, A.B. (2010), 'The presence of business ethics and CSR in the higher education curricula for executives: the case of Spain', Journal of Business Ethics Education, Vol. 7, pp. 25-38.

Ghoshal, S. (2005), 'Bad management theories are destroying good management practices', Academy of Management Learning and Education, Vol. 4 No. I, pp. 75-9I.

Godsey, M. (2007), 'Ethics education: Let the adventure begin!' Journal of Business Ethics Education, Vol. 4, pp. 55-78.

Habermas, J. (1996), Between Facts and Norms: Contributions to a Discourse Theory of Law and Democracy, trans. by Rehg, W., MIT Press, Cambridge, MA.

Hafsi, T. and Tian, Z. (2005), 'Towards a theory of large scale institutional change: The transformation of the Chinese electricity industry', Long Range Planning, Vol. 38, pp. 555-77.

Hodgson, G.M. (2007), 'Institutions and individuals: Interaction and evolution', Organization Studies, Vol. 28, pp. 95-II6.

Kashyap, R., Mir, R and Iyer, E. (2006), 'Towards a responsive pedagogy: Linking social responsibility to firm performance issues in the classroom', Academy of Management Learning and Education, Vol. 5 No. 3, pp. 366-76.

Kearins, K. and Springett, D. (2003), 'Educating for sustainability: Developing critical skills', Journal of Management Education, Vol. 27 No. 2, pp. 188-204.

Kurland, N.B., Michaud, K.E.H., Best, M., Wohldmann, M.E., Cox, H., Pontikis, K. and Vasishth, A. (20I0), 'Overcoming silos: The role of an interdisciplinary course in shaping a sustainability network', Academy of Management Learning and Education, Vol. 9 No. 3 , pp. 457-76.

Lamberg, J-A. and Pajunen, K. (2010), 'Agency, institutional change, and continuity: The case of the Finnish civil war', Journal of Management Studies, Vol. 47, pp. 8I4-36.

McCourt-Larres, P. and Mulgrew, M. (2009), 'A review of an initiative to introduce a short ethics component into a non-ethics course at a UK university', Journal of Business Ethics Education, Vol. 6, pp. 5-24.

MacFarlane, B. (200I), 'Developing reflexive students: Evaluating the benefits of learning logs within a business ethics programme', Teaching Business Ethics, Vol. 5, pp. 375-87.

MacFarlane, B. and Ottewill, R. (2004), 'Business ethics in the curriculum: Assessing the evidence from UK subject review', Journal of Business Ethics, Vol. 54, pp. 339-47.

Matten, D. and Moon, J. (2004), 'Corporate social responsibility education in Europe', Journal of Business Ethics, Vol. 54, pp. 323-37.

Mezias, S.J. and Glynn, M.A. (I993), 'The three faces of corporate renewal: Institution, revolution and evolution', Strategic Management Journal, Vol. I4, pp. 77-Ior.

Mintzberg, H. (2004), Managers not MBAs: A Hard Look at the Soft Practice of Managing and Management Development, FT Prentice Hall, New York.

Moore, G. (2004), 'Regulatory perspectives on business ethics in curriculum', Journal of Business Ethics, Vol. 54, pp. 349-56.

North, D.C. (I990), Institutions, Institutional Change and Economic Performance, Cambridge University Press, Cambridge, UK. 
Okoye, A. (2009), 'Theorising corporate social responsibility as an essentially contested concept: Is a definition necessary?' Journal of Business Ethics, Vol. 89 No. 4, pp. 6r3-27.

Pentland, B.T. (I999), 'Building Process Theory with Narrative: From Description to Explanation', Academy of Management Review, Vol. 24 No. 4, pp. 7II-724.

Pesonen, H.-L. (2003), 'Challenges of integrating environmental sustainability issues into business school curriculum: A case study from the University of Jyvaskyla, Finland', Journal of Management Education, Vol. 27 No. 2, pp. I58-7I.

Petrick, J.A. (20II), 'Three pedagogical tools to advance management integrity capacity', in Wankel, C. and Stachwicz-Stanusch, A. (Eds.), Management Education for Integrity: Ethically Educating Tomorrow's Business Leaders, Emerald, Bingley, UK, pp. 49-7I.

Pettigrew, A.M. (I990), 'Longitudinal field research on change: theory and practice', Organization Science, Vol. I, pp. 267-92.

Pfeffer, J. and Fong, C.T. (2004), "The business school "business": Some lessons from the US experience', Journal of Management Studies, Vol. 4I No. 8, pp. I50I-20.

Plowman, D.A., Baker, L.T., Beck, T.E., Kulkarni, M., Solansky, S.T. and Travis, D.R. (2007), 'Radical change accidentally: The emergence and amplification of small change', Academy of Management Journal, Vol. 50, pp. 515-43.

Poole, M.S., Van de Ven, A.H., Dooley, K. and Holmes, M.E. (2000), Organizational Change and Innovation Processes: Theory and Methods for Research, Oxford University Press, Oxford, UK.

Prasad, P. and Caproni, P.J. (I997), 'Critical theory in the management classroom', Journal of Management Education, Vol. 2I No. 3, pp. 284-9I.

Pring, R (2002), 'The Future Curriculum-But don't forget the Past' in The School of Curriculum Ten Years Hence: Providing Effective Teachers, Occasional Paper no. 14, University Council for the Education of Teachers.

Rands, G.P. and Starik, M. (2009), 'The short and glorious history of sustainability in North American management education', in Wankel, C. and Stoner, J.A.F. (Eds.), Management Education for Global Sustainability, IAP, New York.

Reed, D. (I999a), 'Three realms of corporate responsibility: Distinguishing legitimacy, morality and ethics', Journal of Business Ethics, Vol. 2I, pp. 23-35.

Reed, D. (I999b), 'Stakeholder management theory: A critical theory perspective', Business Ethics Quarterly, Vol. 9, pp. 453-83.

Rusinko, C.A. (2010), 'Integrating sustainability in management and business education: A matrix approach', Academy of Management Learning and Education, Vol. 9 No. 3, pp. 507-I9.

Saka, A. (2003), 'Internal change agents' view of the management of change problem', Journal of Organizational Change Management, Vol. I6, pp. 480-96.

Schein, E.H. (I984), 'Coming to a new awareness of organizational culture', Sloan Management Review, Vol. 25 No. 2, pp. 3-16.

Scott, W. and Gough, S. (2007), 'Universities and sustainable development: the necessity for barriers to change', Perspective, Vol. II No. 4, pp. I07-I5.

Selznick, P. (I996), 'Institutionalism "Old" and "New", Administrative Science Quarterly, Vol. 4I No. 2, pp. 270-277.

Shrivastava, P. (20I0), 'Pedagogy of passion for sustainability', Academy of Management Learning and Education, Vol. 9 No. 3, pp. 443-55.

Smith, J.D. (2004), 'A précis of a communicative theory of the firm', Business Ethics: A European Review, Vol. I3, pp. 317-3I.

Spicer, D.P. (20II), 'Changing culture: A case study of a merger using cognitive mapping', Journal of Change Management, Vol. II, pp. 245-64.

Starik, M., Rands, G., Marcis, A.A. and Clark, T.S. (2010), 'In search of sustainability in management education', Academy of Management Learning and Education, Vol. 9 No. 3, pp. $377-83$. 
Tsoukas, H. and Chia, R. (2002), 'On organizational becoming: Rethinking organizational change', Organization Science, Vol. I3, pp. 567-82.

Tsoukas, H. \& Hatch, M.J. (200I), 'Complex Thinking, Complex Practice: The Case for a Narrative Approach to Organizational Complexity', Human Relations, Vol. 54 No. 8, pp. 979-I,OI3.

Tushman, M.T. and Romanelli, E. (I985), 'Organizational evolution: A metamorphosis model of convergence and reorientation', in Cumings, L.L. and Staw, B.M. (Eds.), Research in Organizational Behavior, JAI Press, Greenwich, CT, pp. I7I-222.

Van de Ven, A.H. and Huber, G.P. (I990), 'Longitudinal field research methods for studying processes of organizational change', Organization Science, Vol. I, pp. 2I3-I9.

Van de Ven, A.H. and Poole, M.S. (I995), 'Explaining development and change in organizations', Academy of Management Review, Vol. 20, pp. 510-40.

Van de Ven, A.H. and Poole, M.S. (2005), 'Alternative approaches for studying organizational change', Organization Studies, Vol. 26, pp. 1377-404.

Van de Ven, A.H. and Sun, K. (20II), 'Breakdowns in implementing models of organization change', Academy of Management Perspectives, Vol. 25 No. 3, pp. 58-74.

Velazquez, L., Munguia, N. and Sanchez, M. (2005), 'Deterring sustainability in higher education institutions: an appraisal of the factors which influence sustainability in higher education institutions', International Journal of Sustainability in Higher Education, Vol. 6 No. 4, pp. 383-91.

Weick, K.E. (I995), Sensemaking in Organizations, Sage, Thousand Oaks, CA.

\section{Appendix}

\section{Follow-up questionnaire on education for sustainable development}

\section{Your subject group:}

OIM [ ] LAW [ ] Marketing [ ] SEIB [ ] A\&F [ ] HRM [ ]

\section{You are:}

Professor/reader [ ] Senior lecturer [ ] Lecturer [ ] Other [ ]

In order to answer the following questions, level descriptors are provided at the end of the questionnaire for your information.

Which level/degree is appropriate for the school to teach sustainable development? Tick as many as appropriate

$\begin{array}{lll}\text { UG } & \text { Level I } & \text { [ ] } \\ \text { UG } & \text { Level 2 } & \text { [ ] } \\ \text { UG } & \text { Level 3 } & \text { [ ] } \\ \text { PG } & \text { MSc } & \text { [ ] } \\ \text { PG } & \text { MBA } & \text { [ ] }\end{array}$


Should modules on sustainable development be compulsory?

$\begin{array}{llll}\text { UG } & \text { Level I } & \text { Compulsory [ ] } & \text { Option [ ] } \\ \text { UG } & \text { Level } 2 & \text { Compulsory [ ] } & \text { Option [ ] } \\ \text { UG } & \text { Level } 3 & \text { Compulsory [ ] } & \text { Option [ ] } \\ \text { PG } & \text { MSc } & \text { Compulsory [ ] } & \text { Option [ ] } \\ \text { PG } & \text { MBA } & \text { Compulsory [ ] } & \text { Option [ ] }\end{array}$

Should the school offer a stand-alone module on sustainable development?

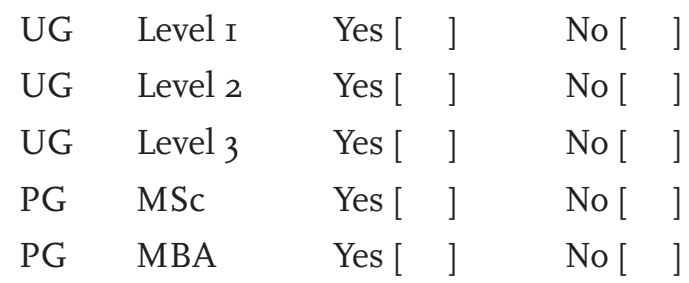

Should contents related to sustainable development be integrated into modules?

$\begin{array}{llll}\text { UG } & \text { Level I } & \text { Yes [ ] } & \text { No [ ] } \\ \text { UG } & \text { Level 2 } & \text { Yes [ } & \text { No [ }] \\ \text { UG } & \text { Level 3 } & \text { Yes [ } & \text { No [ } \\ \text { PG } & \text { MSc } & \text { Yes [ } & \text { No [ } \\ \text { PG } & \text { MBA } & \text { Yes [ } & \text { No [ }\end{array}$

Should the school offer a series of modules on sustainable development running through UG level I to level 3?

Yes [ ] No [ ]

Should modules on sustainable development be developed based on interdisciplinary input?

Yes [ ] No [ ]

Should the school have specialists who teach sustainable development?

Yes [ ] No [ ]

Among the modules you have taught, in which module do you think sustainable development should be taught? Please specify the module title and, if possible, provide some comments on how it should be taught. 
If you were to teach sustainable development in your module, what sort of support would you like to have?

Please provide any further comments. 